are employed to do the work of twelve," would be a disgraceful imposition. If, as you say, language has been employed at some of the meetings of our association and company implying that any such arrangements are to be imported into London, it must have been in my absence, nor would I ever consent to be connected with any such proceedings. In this attempt to substitute for the present indiscriminate gratuitous relief a system of payment by the poor for their medical attendance, on the principle of insurance, it is obvious that the rates of payment must be low, but I am glad to say that we have anticipated your advice to take the well-established sick clubs as our guide. We can only enlist the necessary number of members by the co-operation of the Jarge friendly societies, and we propose to admit their members on the terms which they now pay for their sick clubs, and other members on terms slightly higher. The reason for the difference is that the members of friendly societies are male adults, and most of them have very little illness. Other members would consist largely of women and children, and require more attendance. That these terms can adequately remunerate the medical men we conclude, not merely from the experience of the provident dispensaries in London, the majority of which, as you truly say, is not at present self-supporting, but from the large institutions in the manufacturing district: which are now firmly established and are perfectly independent, and whose offices are sought for by the most respectable practitioners of the district. There is no conceivable reason why what pays so well in those counties should not be equally successful in London, except the prevalence here of a vast system of indiscriminate out-patient relief. If we could obtain the assistance of the medical press and the medical public in reforming the abuses of this system, I have no doubt that something would take its place, in respect to the relief of the mass of ordinary sickness, which would be far more just to the profession and far more satisfactory to the poor. But we have no wish whatever to abolish or even cripule the out-patient practice of the hospitals. On the contrary, we fully recognise their value in medical education, and ouly want to improve them. Still less have we any wish to do injustice to medical men. The present gratuitous system, we beliere, deprives thern in London alone of a very large sum of money annually, which we wish to restare to them; and with patience, \&c., wish on all sides to treat the question fairly. We do not despair of success. It would be a good angury of success, and a long step towards it, if we could eulist the powerfal support of THE LANCET for a plan, the general objects of which you are pleased to stamp with your approval.

I am yours, \&e.,

Great Cumberland-place, July 26th, 1881 . T. HoLMEs.

P.S.-As an example of the income which may be derived from a really self-supporting provident dispensary, allow me to instance that at Leicester their balunce-sheet for 1880 (which I enclose and shall be gled to send to anyone interested in the matter) shows that they receiyed $\$ 4263$, of which $£ 2601$ was paid to the medical officers-viz, $\mathfrak{E 2 2 , 6}$ for ordinary attendance, and $£ 390$ for midwifery fees. Their rates of payment are, I think, somewhat lower than ours. Why should that he impossible in London which is easy at Leicester; or bow is the dignity of medical labour violated in the persons of the medical men (twelve in uumber) who work the dispensary?

\section{CENTRAL AMBLYOPIA IN DIABETES.}

\section{To the Editor of THE LANCET.}

SIR,-In further support of the observations made on this subject by Mr. Nettleship at the last meeting of the Ophthalmological Society, at which I was unable to be present, I wish to say that, some three mouths ago, Dr. Sauntby sent me a case of diabetes, with arnaurosis, for my opinion as to the condition of the eyes, of which I made the fullowing note:- "Central amblyopia fur all culours; sees better in a dull light; eminetropic vision = 15 Snellen."

The patient was a man aged about fifty. There was no ophthalmoscopic signs of disease. Though I made no note as to whether he was a smoker or not, I feel almost sure, speaking from memory, that I made inquiries which resulted in his stating that he was not a smoker, because was much interested and struck by this condition, which I had previously considered peculiar to tobacco, amblyopia being present in diabetes. Unfortunately the man has since died, and I am unable to make any further inquiries on this point.

Birmingham, JuIy 19th, 1881 HENRY EALES.

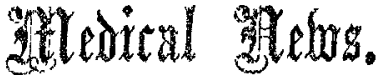

Royal College of Surgeons of ENGland. The following gentlemen, having passed the required ex amination for the diploma, were duly admitted Members of the College at a meeting of the Court of Examiners on the 2lst inst.:-

Atkinson, Thomas Ruell, Fleet-street.

Collins, John Sheill, M.D. Queen's Univ. Irel., Belfast.

Harris, Thomas, Fallowfield, Cheshire.

Haycack, Henry Ed ward, Shrewsbury.

Humphreys, William Carr, L.S.A., Bromsgrove.

Jones, John Hugb, L.K.Q.C.P.I., Talsarn, Carnarpon.

Joseph, J. B. Edgar, Trinidad, West Indies.

Lane, James Oswald, B.A. Cantah., Hereford.

Ray, William Barker, Newtown, Montgomery.

Robertson, C. A. James, Manchester.

Robinson, Charles William, L.S.A., North Shields.

Schacht, Franc Frederic, B.A. Cantab., Clifton, Bistol.

Tait, Henry Brewer, Highbury-park.

Teevan, Henry, L S.A., Nottingham-place.

Whelan, George, Ticehurst-street.

Wilson, Henry, Sale, Cheshire.

The following gentlemen were aojmitted Members of the College on the 22ud inst. :-

Bagshaw, Thomas Washington, Birkenhear.

Boobbyer, Philjo, Hendon.

Bray, Frnest Erl ard, L.S.A., Rognor, Sussex.

Gale, Arthur Knight, Chil worti, Oxun

Gaskin, Thumas Law, Barbadoes.

Gross, Asher, Leeds.

Hardwicke, Richard Reece, Tonbridge.

Herringham, Wilmot Parker, Bedford-square.

King, W. H. Tindal, L S.A., Plymouth.

Pittard, Marmaduke, Guernsey.

Pounds, Thomas Hexderson, Chatham.

Rimell, Alfred Tum, Eardley-crescent.

Roberts, Richard Pritcbard, L.S.A., Bangor.

Vincent, Philip, Fintham Cross, Herts.

Wickham, Walter, L.s.A, Chew Stoke, Somerset.

Woolley, George 'I'albot, Upper Bedford-place.

Pratt, James John, Newtown, Montgomery.

The following gentlemen were admitted Members of the College on the 25 th iust. :-

Alderton, Merbert Charles, Shotley, Suffulk.

Brown, C. W. Haig, Godalming.

Coates, Willian, Worksop.

Davies, Wvin Vimnton, I.S A., Cymmer, South Wales.

Oraper, James William, Barnsbury.

Grindon, Francis Janıs, L.S.A., Oiney, Bucks.

Hern, Jobn, M. B. Eitin, Ashburton, Devon.

O'Reilly, Archibaid Thomas, Sydney, New South Wases.

Robinson, Huoh shapter, Sydenham-hill.

Walker, Charles Rutherham, Eckington, Derbyshire.

Webber, Edward Sanuel, B.A. Cantab., Abergavenny

The following gentlemen were admitted Members of the College on the $26 \mathrm{i}$ inst.:-

Bickle, Leonard Watkins, St. Leonards-on-Sea.

Cook, Augustus Henry, Hampsteal.

Dowson, John, St. Juhn's Wood.

Wdwards, Arthur Red, Milmesbury.

Fitch, Richard Aubrey, Kidderminster.

Lyster, C. R Chaworti, Leseness Heath.

Perks, Robert Howell, Cardiff.

Prothero, Richard, Liverpool.

Rice, Bernard, Stratford-on-Avon.

Rudd, Charles Fredertck, I. S.A., Wymonlham

Russell, John Hutchinsen, L S.A., Walthiam-cross

Rygate, Devid fohn, L $S$.A., Cannon-street-rualt

Serjeant, George, Callington, Cornwall

Steer, Willaru, L.S.A., Salcombo

'iuke, Charles Holesworth, Cheswick.

The fullowing gentlemen were admilted ifembers of the College on the $27 \mathrm{~h}$ inst. :-

Atterbury, Walter, L.S.A., Oppidans-roat.

Burrows, C. IV. Givines, L.S.A., Evkington, Derhyshire

Cabill, John, Albert-gate.

Clifton, Frederick Wiliam, Derby.

Cornish, Charles Teytum, Derby.

Duff, Crarles Heury, Gray's-inton.

Fell, Walter, Vincent-square.

Groom William B A Cisheach

Groom, William, B. A. Cantab.

Robins, George Norman, Buxton. 